\title{
SERAPAN NITROGEN BIBIT ROTAN PADA PERLAKUAN PUPUK ORGANIK DAN ANORGANIK
}

\section{NITROGEN UPTAKE UNDER INORGANIK AND ORGANIK FERTILIZER}

\author{
Lisa Indriani Bangkele ${ }^{1 *}$ \\ ${ }^{1}$ Program Studi Agroteknologi, Fakultas Pertanian, Universitas Alkhairaat, Jl. Diponegoro No. 39, \\ Palu Sulawesi Tengah 94221, Indonesia
}

\begin{abstract}
ABSTRAK
Indonesia sebagai penghasil dan pemasok utama rotan dunia, namun sebagian besar produksi rotan Indonesia mengandalkan sumber rotan alam. Fakta bahwa rotan alam umumnya dipanen setelah berumur lebih dari 4 tahun, tidak sebanding dengan pemanenan yang dilakukan tiap saat dan mengancam kelestarian rotan, sehingga penelitian budidaya rotan menjadi penting. Penelitian ini fokus pada pertumbuhan serta serapan nitrogen (nitrogen jaringan) bibit rotan varietas Noko (Daemonorops sp.) sebagai respons dari pupuk organik dan anorganik. Penelitian dilakukan di rumah kaca UNTAD, menggunakan rancangan faktorial 2 (dua) faktor. Faktor I terdiri atas 2 (dua) taraf, yaitu: (B0) tanpa bokashi, dan (B1) bokashi 10 t/Ha. Faktor II terdiri atas 7 (tujuh) variasi perlakuan Nitrogen. Hasil penelitian menunjukkan perlakuan pupuk organik maupun pupuk anorganik berpengaruh tidak nyata terhadap berat kering maupun serapan nitrogen $(\mathrm{N})$ atau $\mathrm{N}$ jaringan. Namun perlakuan dengan bokashi menunjukkan kecenderungan berat kering dan juga serapan $\mathrm{N}$ atau $\mathrm{N}$ jaringan lebih tinggi dibandingkan perlakuan tanpa bokashi. Pada penelitian ini, perlakuan dengan bokashi ditambahkan pupuk Urea memberikan pengaruh terbaik terhadap pertumbuhan bibit rotan Noko .
\end{abstract}

Katakunci: rotan, pupuk organik, pupuk anorganik, serapan nutrisi, nitrogen jaringan

\section{ABSTRACT}

Indonesia as the world's major producer and supplier of rattan, but most of Indonesia's rattan production relies on natural rattan sources. The fact that natural rattan is generally harvested after the age of more than 4 years, is not proportional to harvesting at any time, and threatens the preservation of rattan, so research on rattan cultivation is important. This study focuses on the growth and absorption of Noko rattan seedlings varieties (Daemonorops sp.) in response of organic and inorganic fertilization. Research was conducted in the glass house of UNTAD, using factorial design of 2 (two) factors. Factor I consists of 2 (two) levels, namely: (BO) without bokashi, and (B1) bokashi $10 \mathrm{t} / \mathrm{Ha}$. Factor II consists of 7 (seven) variations of Nitrogen and Phosphorus treatments. The results showed that the treatment of organic fertilizer and inorganic fertilizer had no significant effect on dry weight or nitrogen uptake $(N)$ or $N$ network. However treatment with bokashi showed a tendency of dry weight and alsoN uptake or $N$ tissue higher than treatment without bokashi. In this study, treatment with bokashi added Urea fertilizer gives the best influence on the growth of Noko rattan seedlings.

Keywords: rattan, organic fertilizer, inorganic fertilizer, nutrient uptake, nitrogen tissue

\section{Pendahuluan}

Pengaruh pupuk berbeda tergantung pada jenis pupuk, media tumbuh jenis tanaman dan juga ekologi. Dalam penelitian

\footnotetext{
${ }^{*}$ Penulis Korespondensi.

E-mail: lisa_ib15@yahoo.com

Telp: +62-81330319695
}

terkait pupuk, baik pupuk organik maupun pupuk anorganik sudah banyak dikaji pengaruhnya terhadap perubahan morfologi dan fisiologi tanaman, baik pada tajuk maupun akar. Pupuk organik mempengaruhi biogeo-kimiawi tanah dan berpengaruh terhadap pertumbuhan tanaman. Pupuk organik memiliki peranan terutama untuk agregasi struktur tanah sehingga menjadi lebih gembur. Selain itu pupuk organik merupakan 


\section{Jurnal Oazotech 8 (1) 34-39}

sumber karbon, nitrogen, dan mineral lain jika terurai. Bahan organik juga berperan meningkatkan populasi mikro-organisme sehingga meningkatkan mineralisasi bahan organik. Secara umum mineralisasi pupuk organik pada fisiologi tanaman adalah meningkatkan pertumbuhan akar dan meningkatkan serapan nutrisi (Tan dan Nopamornbodi, 1979; Chen, dkk., 2004; Pinton, dkk., 2007), sebagai akibat meningkatnya mineralisasi bahan organik. Mineralisasi bahan organik juga meningkatkan ketersediaan $\mathrm{N}$, dan merangsang terbentuknya IAA sehingga mempengaruhi pertumbuhan akar. Indole-3Acetid Acid (IAA) diketahui sebagai auxin alami mampu meningkatkan pemanjangan sel, dominasi apikal dan perakaran (Cheng, dkk., 2016). Penelitian mengenai pengaruh pupuk organik terhadap tanah dan respons akar kurang mendapat perhatian, mengingat karakteristik bahan organik yang sangat heterogen, namun pada penelitian ini akan diselidiki pengaruh pupuk organik mempertimbangkan bahwa peranan bahan organik terhadap pertumbuhan tajuk dan akar tanaman terutama tanaman hutan sangat penting. Ada respon positif pertumbuhan tanaman hutan dengan bahan organic yang memacu perubahan nutrisi tanah dan iklim mikro akibat bahan organik (Wei, dkk., 2012).

Penelitian ini juga menggunakan nitrogen anorganik dari sumber yang berbeda (Urea dan ZA) yang memiliki karakteristik kimia berbeda seperti $\mathrm{pH}$ larutan yang pada akhirnya juga akan memberikan pengaruh berbeda pada pertumbuhan. Selain itu akar selektif dalam penyerapannya terhadap beberapa ion, sehingga kompisisi relatif ion dalam sistem tubuh tanaman sering berbeda dengan komposisinya di dalam tanah. Selektivitas tergantung pada spesies tanaman, oleh karena itu komposisi ion pada daun tanaman berbeda diantara spesies dan tergantung pada komposisi ion dalam larutan tanah. Tanaman dapat digolongkan sebagai akumulator atau rejektor terhadap ion (Gregory, 2006). Selektivitas tanaman ditunjukkan Zhang, $d k k$., (2004) yang mendapatkan biomassa tanaman, pertumbuhan akar dan total serapan $\mathrm{N}$ meningkat dengan perlakuan $\mathrm{NH}_{4}{ }^{+}$dibandingkan perlakuan $\mathrm{NO}_{3^{-}}$.

Penggunaan rotan sebagai tanaman indikator, mempertimbangkan potensi produksi rotan terus berkurang. Pemanenan yang intensif mengancam kelestarian rotan alam, sehingga budidaya rotan menjadi penting. Lambatnya pertumbuhan rotan menjadi kendala dalam studi
e-ISSN : 2621-7236

p-ISSN : 1858-134X

menyangkut pertumbuhan tanaman. Tidak banyak studi mengenai teknik budidaya rotan, misalnya Haider, M.R., $d k k$. (2014) yang hanya meneliti waktu perkecambahan rotan dan perbanyakan rotan melalui invitro Zoro Bi, I.A., dan Kouakou, K.L., (2004), sehingga sangat sedikit pengetahuan mengenai respos rotan terhadap pupuk, lebih khusus lagi untuk jenis rotan endemik Sulawesi seperti jenis rotan Noko (Daemonorops sp.).

Tujuan penelitian ini untuk mengkaji respons pertumbuhan dan serapan nitrogen (nitrogen jaringan) bibit rotan terhadap pupuk anorganik $\mathrm{N}$ dari sumber berbeda (Urea atau ZA), dan pupuk organik bokashi.

\section{Metode Penelitian}

Penelitian dilakukan di rumah kaca UNTAD, menggunakan pot yang berdiameter atas $15 \mathrm{~cm}$, diameter bawah pot $13 \mathrm{~cm}$ dengan tinggi $15 \mathrm{~cm}$. Desain percobaan menggunakan rancangan acak kelompok (RAK) dengan 2 (dua) faktor. Faktor I terdiri atas 2 (dua) taraf dan faktor II terdiri atas 7 (tujuh) variasi perlakuan, menggunakan rancangan faktorial 2 (dua) faktor. Faktor I terdiri atas 2 (dua) taraf, yaitu: (B0) tanpa bokashi, dan (B1) bokashi 10 t/Ha. Faktor II terdiri atas 7 (tujuh) variasi perlakuan Nitrogen dan Fosfor, yaitu: (F0) Kontrol; (U1) N-Urea 50 $\mathrm{kg} \mathrm{N} / \mathrm{Ha}+\mathrm{P} 50 \mathrm{~kg} \mathrm{P} / \mathrm{Ha}$; (U2) N-Urea $100 \mathrm{~kg}$ N/Ha + P 50 kg P/Ha; (U3) N-Urea 100kg N/Ha + P $100 \mathrm{~kg} \mathrm{P} / \mathrm{Ha}$; (ZA1) N-ZA $50 \mathrm{~kg} \mathrm{~N} / \mathrm{Ha}+\mathrm{P}$ $50 \mathrm{~kg}$ P/Ha; (ZA2) N-ZA $100 \mathrm{~kg}$ N/Ha + P $50 \mathrm{~kg}$ $\mathrm{P} / \mathrm{Ha}$; (ZA3) N-ZA $100 \mathrm{~kg} \mathrm{~N} / \mathrm{Ha}+\mathrm{P} 100 \mathrm{~kg}$ $\mathrm{P} / \mathrm{Ha}$.

Perlakuan diulang sebanyak 3 (tiga) kali, sehingga diperoleh $2 \times 7 \times 3=42$ unit percobaan. Pengacakan dilakukan menurut cara yang dikembangkan Gomez dan Gomez (1984). Untuk menguji pengaruh perlakuan yang dicobakan dilakukan Analisis Varians. Apabila hasil analisis tersebut menunjukkan pengaruh nyata dilakukan uji lanjut beda nyata jujur (BNJ) taraf 0,05 untuk menentukan perbedaan antar perlakuan, interaksi, dan perlakuan yang terbaik.

\section{Hasil dan Pembahasan}

Hasil penelitian menunjukkan perlakuan pupuk organik maupun pupuk anorganik berpengaruh tidak nyata terhadap berat kering maupun nitrogen $(\mathrm{N})$ jaringan bibit rotan. Namun perlakuan dengan bokashi menunjukkan kecenderungan berat kering tajuk lebih tinggi 


\section{Jurnal Agrotech 8 (1) 34-39}

$(2,07 \mathrm{~g}-3,05 \mathrm{~g})$ dibandingkan perlakuan tanpa bokashi $(2,09 \mathrm{~g}-2,70 \mathrm{~g})$. Hal ini menunjukkan pengaruh positif pupuk organic bokashi terhadap pertumbuhan tanaman, yang sesuai dengan Baiyeri dan Tenkouano (2008) dalam hasil penelitiaannya juga mendapatkan hubungan positif antara bahan organik dengan pertumbuhan dan produksi tajuk dan akar tanaman.

Pada penelitian ini menunjukkan kontrol memperlihatkan pertumbuhan yang tidak berbeda nyata dengan semua perlakuan pupuk anorganik $\mathrm{N}$ dan P. Pertumbuhan bibit tanaman rotan, seperti halnya tanaman dari family Palmae lainnya sangat lambat di awal pertumbuhan dan biasanya lebih dipengaruhi sifat genetif benih. Sejalan dengan Ariyanti, dkk. (2017), Cicek dan Tilki (2007) yang menyatakan pertumbuhan awal bibit tanaman lebih dipengaruhi sifat genetif tanaman. Namun tidak sejalan dengan hasil penelitian Andrews (2006) yang mendapatkan pemupukan NO3 mampu menaikkan berat kering tanaman tembakau, dan tanaman Miscanthus giganteus (Lee, $d k k ., 2017$ )

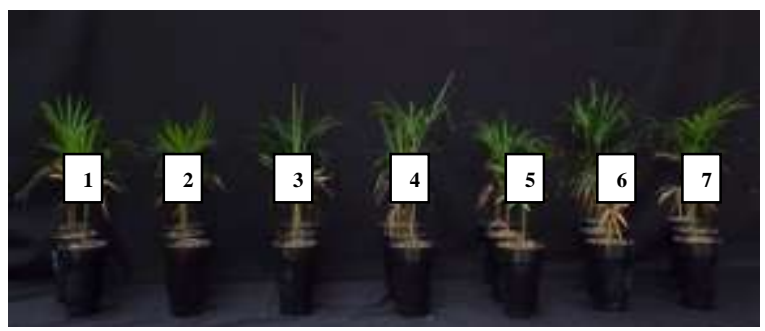

Gambar 1.Keragaan bibit rotan pada perlakuan pupuk anorganik $\mathrm{N}$ dan $\mathrm{P}$; control (1) dan pupuk $\mathrm{N}$-Urea+P $(2,3,4)$, pupuk $\mathrm{N}-\mathrm{ZA}+\mathrm{P}(5,6,7)$

Namun sebaliknya hasil penelitian menunjukkan berat kering akar cenderung lebih rendah dengan perlakuan bokashi. Hal ini menunjukkan bahwa kekurangan hara justru memacu pertumbuhan akar. Hasil ini sejalan dengan pendapat Lonhienne, dkk. (2014) mendapatkan kekurangan $\mathrm{N}$ dapat memaksa tanaman untuk meningkatkan percabangan, panjang dan kepadatan akar tanaman. Asam humat menstimulasi pertumbuhan akar, tetapi intensitas respons akar tanaman bervariasi. Namun kontras dengan hasil penelitian Jindo, dkk., (2012) pada tanaman pinus menunjukkan bahwa perlakuan asam humat (HA) meningkatkan area perakaran $30-70 \%$. Asam humat yang dihasilkan melalui pengomposan bahkan dapat meningkatkan panjang akar $30-40 \%$, dan berat kering akar $25-30 \%$ lebih tinggi dibandingkan kontrol.

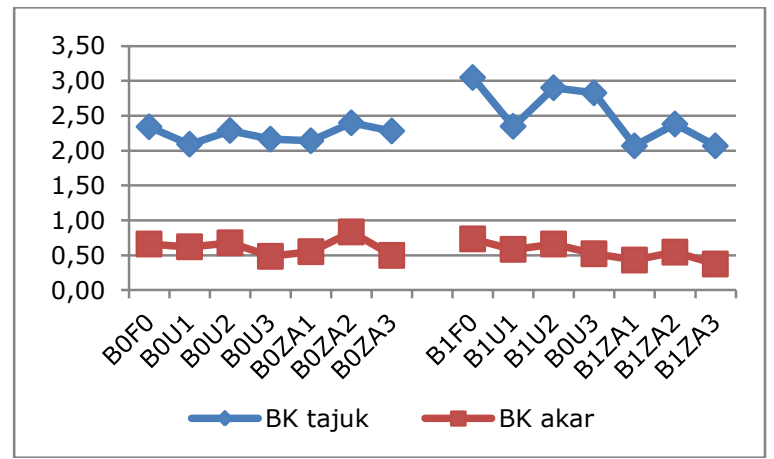

Gambar 2.Berat kering tajuk dan akar pada perlakuan pupuk organik dan pupuk anorganik $\mathrm{N}$ dan $\mathrm{P}$.

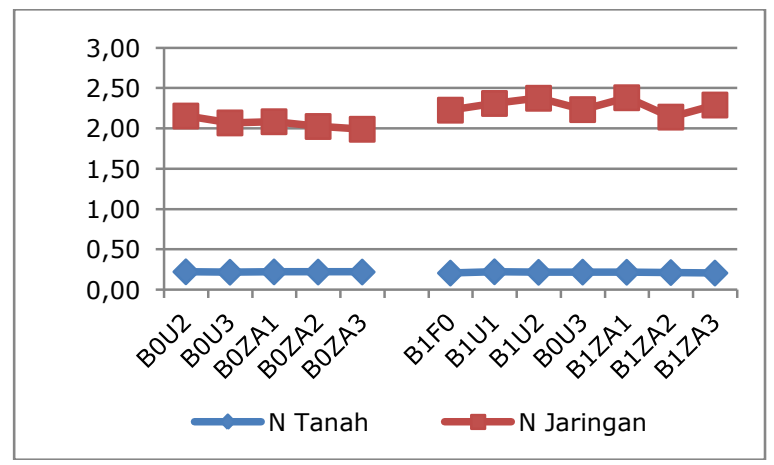

Gambar 3.Perbandingan Nitrogen $(\mathrm{N})$ tanah dengan $\mathrm{N}$ jaringan bibit rotan.

Hasil penelitian ini menunjukkan $\mathrm{N}$ tanah berpengaruh sangat tidak nyata untuk semua perlakuan pupuk anorganik $\mathrm{N}$ baik $\mathrm{N}$-Urea maupun N-ZA dan pupuk organik, dan penambahan pupuk organik (bokashi) juga tidak mempengaruhi $\mathrm{N}$ tanah (Gambar 3). Namun hasil penelitian menunjukkan $\mathrm{N}$ jaringan pada perlakuan bokashi lebih tinggi $(2,14-2.38)$ dibandingkan perlakuan tanpa bokashi (1,99 2,15), tetapi tidak berpengaruh nyata pada perlakuan N-Urea dan N-ZA. Menunjukkan serapan $\mathrm{N}$ lebih efektif dengan adanya penambahan bokashi. Bahan organik mampu meningkatkan efisiensi serapan hara, sejalan dengan pendapat beberapa peneliti bahwa humat dari bahan organik meningkatkan serapan nutrisi tanaman (Tan dan Nopamornbodi, 1979; Chen, $d k k .$, 2004; Pinton, $d k k ., 2007)$.

Pada penelitian ini perlakuan pupuk anorganik N-Urea maupun N-ZA tidak berpengaruh nyata terhadap serapan $\mathrm{N}$ atau $\mathrm{N}$ jaringan, namun perlakuan dengan penambahan pupuk organik bokashi mampu meningkatkan serapan $\mathrm{N}$ atau $\mathrm{N}$ jaringan, sehingga 
berpengaruh nyata terhadap produksi biomassa atau berat kering bibit rotan (Gambar 3). Hal ini tidak sejalan dengan beberapa penelitian yang menunjukkan pemupukan $\mathrm{N}$ memiliki korelasi linear dengan produksi berat kering dan konsentrasi $\mathrm{N}$ pada jaringan tanaman (Tan dan Hogan, 1998).

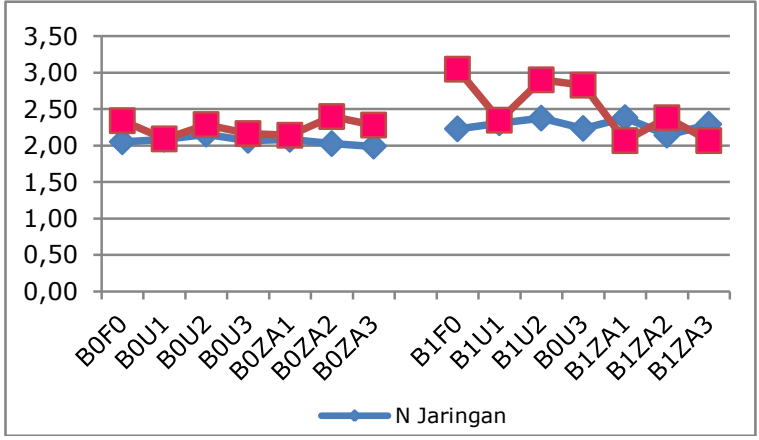

Gambar 3.Berat kering tajuk dan akar pada perlakuan pupuk organik dan pupuk anorganik $\mathrm{N}$ dan P.

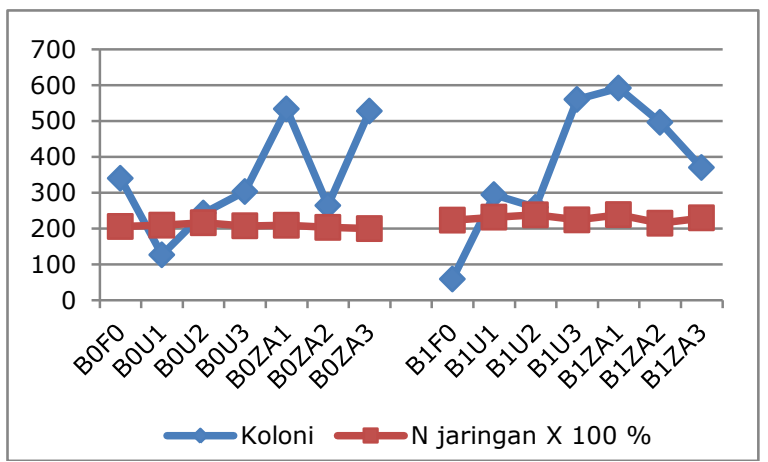

Gambar 4.N jaringan dan populasi koloni tanah pada perlakuan pupuk organik dan pupuk anorganik $\mathrm{N}$ dan $\mathrm{P}$.

Hasil penelitian menunjukkan perlakuan berpenguh terhadap populasi koloni. Penambahan bahan organik ke dalam tanah meningkatkan aktivitas organisme tanah, dan peningkatannya sangat berkaitan dengan kandungan bahan organik alami di dalam tanah itu sendiri. Bahan organik meningkatkan populasi mikroorganisme sehingga meningkatkan mineralisasi bahan organik. Penelitian Cheng, dkk. (2016) menunjukkan mineralisasi bahan organik meningkatkan ketersediaan $\mathrm{N}$, dan merangsang terbentuknya IAA sehingga mempengaruhi pertumbuhan akar.

Pada penelitian ini peningkatan populasi akibat perlakuan tidak mempengaruhi serapan $\mathrm{N}$ atau N-Jaringan, hal tersebut kontras dengan banyak hasil penelitian sebelumnya. Akar berinteraksi secara intensif dengan mikroorganisme yang mana memberi pengaruh secara langsung meningkatkan ketersediaan dan serapan hara, atau secara tidak langsung melalui pengaruhnya terhadap peningkatan pertumbuhan akar (Richardson, dkk., 2009; Richardson, dkk., 2007; Jacobs, $d k k$., 2003). Mikroorganisme yang bersimbiosis (infecting microorganism) seperti mikoriza mempengaruhi pertumbuhan akar dan tanaman secara langsung (Richardson, dkk.,2009), seperti pada hasil penelitian Caravaca, dkk. (2003) menunjukkan bahwa inokulasi mikoriza pada bibit tanaman Rhamnus lyciodides meningkatkan serapan nutrisi, khususnya $\mathrm{N}$ dan $\mathrm{P}$ melalui perluasan permukaan serapan, meningkatkan system perakaran, dan memproduksi senyawa yang mendukung pertumbuhan. Sedangkan pada mikroorganisme tidak bersimbiosis (non infecting microorganism) mempengaruhi serapan nutrisi tanaman melalui pengaruhnya pada; (i) pertumbuhan, morfologi dan fisiologi akar, (ii) fisiologi dan perkembangan tanaman, (iii) ketersediaan nutrisi, (iv) proses pengambilan (uptake) nutrisi (Marschner, 1995). Mikroorganisme rizosfir ini meningkatkan aquisisi $\mathrm{N}, \mathrm{P}$, dan $\mathrm{K}$ terutama melalui pengaruhnya terhadap morfologi dan fisiologi akar. Suplai N tinggi mempengaruhi serapan nutrisi dan secara tidak langsung melalui pertumbuhan akar Mikroorganisme rizosfir meningkatkan nilai pertukaran siklus $\mathrm{N}, \mathrm{P}$ dan karbon $(\mathrm{C})$ organik dari ikatan organik dan nutrisi mikro lainnya (Marschner, 1995).

\section{Kesimpulan}

Pupuk anorganik $\mathrm{N}$ baik $\mathrm{N}-$ Urea maupun $\mathrm{N}-\mathrm{ZA}$ menunjukkan pengaruh tidak nyata terhadap berat kering dan serapan $\mathrm{N}$ atau $\mathrm{N}$ jaringan. Untuk tanaman tahunan dengan pertumbuhan awal yang sangat lambat, pertumbuhan bibit lebih banyak dipengaruhi sifat genetif benih, dan belum banyak menunjukkan respon terhadap pemupukan. Namun pengaruh pupuk $\mathrm{N}$ anorganik lebih nyata jika ditambahkan pupuk organik. Penelitian ini menunjukkan penambahan bokashi dapat memperbaiki serapan hara, walau berat kering tajuk dan akar tidak berpengaruh nyata.

\section{Ucapan Terima Kasih}

Terima kasih disampaikan kepada Fakultas pertanian Universitas Alkhairaat Palu yang telah mendanai Jurnal ini. Juga kepada Universitas Alkhairaat Palu, dan Universitas Tadulako Palu, yang merupakan wadah saya untuk mengabdi dan menuntut ilmu. 
Jurnal azrotech 8 (1) 34-39

\section{Daftar Pustaka}

Andrews, M., Raven, J.A., Lea, P.J.,Sprent, J.I. 2006. A Role for shoot Protein in ShootRoot dry Matter Allocation in higher Plants. Annals iof Botany. 97(1):3-10

Ariyanti, M., Suherman, C., Anjasari, I.R.D., Sartika, D. 2017. Respon pertumbuhan Bibit Nilam Aceh (Pogostemon cablin Benth) Klon Sidikalang pada Media Tanam Subsoil dengan Pemberian Pati Beras dan Pupuk Hayati. Jurnal Kultivasi. 16(3): 394-401.

Baiyeri, K.P. dan Tenkouano, A. 2008. Manure Placement Effect on Root and Shoot growths and nutrient uptake of "PITA 14" plantain Hybrid (Musa sp AAAB). African Journal of agricultural research. 3(1): 013-021

Caravaca, F., Figueroa, D., Roldan, A. dan Aguilar, A.C. 2003. Alteration in Rhizosphere Soil properties of Afforested Rhamnus lycioides Seedlings in Shortterm Response to Mycorrhizal Inoculation with Glomus intreredices and Organic Amendement. Environt-ment Management. 3(3): 412-420.

Chen, X., Zhang, J., Chen, Y., Li, Q., Chen, F., Yuan, L. 2014. Changes in root Size and Distribution in Relation to Nitrogen Accumulation During Maize Breeding in China. Plant Soil. 374(1-2): 121-130.

Cheng, Y., Jiang, Y., Wu, Y., Valentine, T.A. dan Li, H. 2016. Soil Nitrogen status Modifies Rice Root Response to Nematode-Bacteria Interactions in the Rhizosphere. PLOS one. DOI: 10 (137): 1-19.

Cicek, E. dan Tilki, F. 2007. Seed Size Effect on Germination, Survival and Seedling Growth of Castanea sativa Mill. Journal of Biological Sciences. 7(2): 438-441.

Gregory, P.J. dan Hinsinger, P., 1999. New Approaches to Studying chemical and Physical Changes in the Rhizosphere: an Overview. Plant and Soil. 211: 1-9.
e-ISSN : 2621-7236

p-ISSN : 1858-134X

Gunawan. 2002. Keragaman Perdagangan Rotan dan Produk Rotan Indonesia di Pasar Domestik dan Stimulasi Kebijakan. Disertasi. Program Pascasarjana. Institut Pertanian Bogor. Tidak dipublikasikan.

Gunawan. 2005. Ketersediaan Bahan Baku dalam Mendukung Peningkatan Ekspor Produk Rotan dan Permasalahannya. Fasilitasi Usaha Bidang Pemasaran dan Produksi Pelaku Usaha Hasil Hutan Non Kayu (Rotan). Direktorat Bina Pengolahan dan Pemasaran Hasil Hutan. Direktorat Jenderal Bina Produksi Kehutanan. Jakarta.

Haider, M. R., Alam, Md. S., Hossain, Md. A., Shukor, N. A. 2014. Impact of PreSowing Treatment on Seed Germination and Seedling Growth Attributes of Calamus longisetus Griff. At Nursery and Field Conditions. Journal of Food, Agriculture \& Environment. WFL Publisher Science and Technology. 12(3\&4): 395-399.

Jacobs, D. F., Rose, R. dan Haase, D. L. 2003. Development of Douglas-Fir Seedling Root Architecture in Response to Localized Nutrient Supply. Canadian Journal of Forest Research. 33: 118-125.

Jindo, K., Martim, S. A., Navarro, E. C., Alfocea, P. F., Hernandez, T., Garcia, C., Aguiar, N. O. dan Cannellas, 1.P. 2012. Root growth Promotion by humic Acids from composted and Non-Composted Urban Organic Wastes. Plant Soil. 353: 209220.

Lee, M., Wycisto, A., Guo, J., Lee, D.K. 2017. Nitrogen Fertilization Effect on Biomass Production and Yield Components of Miscanthus xgiganteus. Front plant Science. 8:544.

Lonhienne, T.G.A., Trusav, Y., Young, A., Rentsch, D., Nasholm, T., Schmidt, S., Paungfoo-Lonhienne, C. 2014. Effects of internally Supplied Protein on Root Morphology and Biomass Allocation in Arabidopsis. Scientific Reports. 4: 5055/ DOI: 10: 1038 


\section{Jurnal Agrotech 8 (1) 34-39}

Marschner, H. 1995. Mineral Nutrition of Higher Plants. Academic Press. Harcourt Brace \& Company, Publisher. London.

Pinton, R., Varanini, Z. dan Nannipieri, P. 2001. The Rhizosphere. Biochemistry and Organic Substances at Soil-Plant Interface.Marcel Dekker,Inc. New York.

Rachman, O. dan Jasni. 2013. Rotan, Sumberdaya, Sifat dan Pengolahannya. Pusat Penelitian dan Pengembangan Keteknikan Kehutanan dan Pengolahan Hasil Hutan. Balitbanghut. Kementrian Kehutanan. Bogor.

Richardson, A.E., George, T.S., Jakobsen, I., Simpson, R.J. 2007. Plant Utilization of Inositol Phosphates: in Turner BL, Richardson AE., Mullaney, E.J.(eds) Inosil Phosphates: linking Agriculture and the Environtment. CAB International. Wallingford.pp. 242-260.

Richardson, A. E., Barea, J. M., McNeill, A. M. dan Combaret, C. P. 2009. Acquisition of Phosphorus and Nitrogen in the Rhizosphere and Plant Growth Promotion by Microorganisms. Plant Soil. 321: 305-339.

Sanusi, D. 2012. Rotan Kekayaan Belantara Indonesia. Brilian Internasional. Surabaya.

Tan, W. dan Hogan, G.D., 1998. Dry Weight an $N$ Partitioning in Relation to Substrate $N$ Supply, Internal Status and Developmental Stage in Jack Pine (Pinus banksiana Lamb.) seedlings : Implications for Modelling. Annals of Botani. 81:195-201.
e-ISSN : 2621-7236

p-ISSN : 1858-134X

Wei, X., Li, Q., Waterhouse, M. J. dan Armleder, H. M. 2012. Organic Matter Loading Affects Lodgepole Pine Seedling Growth. Environmental Management. 49: 11431149.

Zhang, dkk., 2004. Nitrogen Fertilization on uptake of Soil Inorganic Phosphorus Fraction in the Wheat Root Zone. Soil Science Society of America Journal. 68(6): 1896.

Zoro Bi, I. A. dan Kouakou, K. L. 2004. Vegetative Propagation Methods Adapted to Two Rattan Species Laccosperma leave and $L$. Secundiflorum. Tropicultura. 22(4): 163167.

Tan, W. dan Hogan, G.D., 1998. Dry Weight an $N$ Partitioning in Relation to Substrate $N$ Supply, Internal Status and Developmental Stage in Jack Pine (Pinus banksiana Lamb.) seedlings : Implications for Modelling. Annals of Botani. 81:195-201.

Wei, X., Li, Q., Waterhouse, M. J. dan Armleder, H. M. 2012. Organic Matter Loading Affects Lodgepole Pine Seedling Growth. Environmental Management. 49: 11431149.

Zhang, dkk., 2004. Nitrogen Fertilization on uptake of Soil Inorganic Phosphorus Fraction in the Wheat Root Zone. Soil Science Society of America Journal. 68(6): 1896.

Zoro Bi, I. A. dan Kouakou, K. L. 2004. Vegetative Propagation Methods Adapted to Two Rattan Species Laccosperma leave and L. Secundiflorum. Tropicultura. 22(4): 163-167. 